University of Nebraska - Lincoln

DigitalCommons@University of Nebraska - Lincoln

Faculty Publications from the Harold W. Manter Laboratory of Parasitology

2-1994

\title{
New Morphological Characters for Identifying Individual Specimens of Haemonchus spp. (Nematoda: Trichostrongyloidea) and a Key to Species in Ruminants of North America
}

J. Ralph Lichtenfels

Animal Parasitic Disease Lab, ARS, United States Department of Agriculture, 2jrcgl@gmail.com

P. A. Pilitt

United States Department of Agriculture, Agricultural Research Service

Eric P. Hoberg

United States Department of Agriculture, Agricultural Research Service, ehoberg@ggpl.arsusda.gov

Follow this and additional works at: https://digitalcommons.unl.edu/parasitologyfacpubs

Part of the Parasitology Commons

Lichtenfels, J. Ralph; Pilitt, P. A.; and Hoberg, Eric P., "New Morphological Characters for Identifying Individual Specimens of Haemonchus spp. (Nematoda: Trichostrongyloidea) and a Key to Species in Ruminants of North America" (1994). Faculty Publications from the Harold W. Manter Laboratory of Parasitology. 605.

https://digitalcommons.unl.edu/parasitologyfacpubs/605

This Article is brought to you for free and open access by the Parasitology, Harold W. Manter Laboratory of at DigitalCommons@University of Nebraska - Lincoln. It has been accepted for inclusion in Faculty Publications from the Harold W. Manter Laboratory of Parasitology by an authorized administrator of DigitalCommons@University of Nebraska - Lincoln. 


\title{
NEW MORPHOLOGICAL CHARACTERS FOR IDENTIFYING INDIVIDUAL SPECIMENS OF HAEMONCHUS SPP. (NEMATODA: TRICHOSTRONGYLOIDEA) AND A KEY TO SPECIES IN RUMINANTS OF NORTH AMERICA
}

\author{
J. R. Lichtenfels, P. A. Pilitt, and E. P. Hoberg \\ Biosystematic Parasitology Laboratory, Livestock and Poultry Sciences Institute, \\ U.S. Department of Agriculture, Beltsville, Maryland 20705-2350
}

ABSTRACT: The large stomach worms Haemonchus contortus, Haemonchus placei, and Haemonchus similis are important pathogens of cattle and sheep. This paper describes characteristics of surface cuticular ridges (synlophe), which for the first time provide morphological criteria for identifying individual adult specimens of either sex. The diagnostic patterns of the synlophe on the anterior half of specimens can be observed at $400 \times$ in temporary mounts on glass slides. The synlophe can be studied in cleared preserved specimens or in living or freshly thawed frozen specimens mounted in water. The synlophe of $H$. contortus has 30 ridges in the region of the posterior half of the esophagus, 4 fewer than $H$. place $i$ and $H$. similis. The 4 extra ridges of $H$. placei and $H$. similis are consistently located bilaterally to the 3 ventralmost and the 3 dorsalmost ridges. The 4 extra ridges of $H$. similis extend to the end of the synlophe posterior to midbody, but in $H$. place $i$ they extend posteriorly only to the end of the anterior quarter of the nematode. A key is included to the 3 species of Haemonchus parasitic in domestic sheep and cattle using characteristics of spicules, female reproductive system, female tail, and the synlophe.

Three species of the genus Haemonchus Cobb, 1898 , are known to occur in domestic and wild ruminants of North America. They are common parasites of domesticated ruminants and have achieved a worldwide distribution in part due to the movement of their economically important hosts. These 3 species of large stomach worms are among the most pathogenic nematodes of sheep, cattle, and goats worldwide, causing significant production losses due to morbidity, mortality, costs of treatment, and suboptimal use of contaminated pastures (Gibbs and Herd, 1986).

Haemonchus contortus (Rudolphi, 1803) Cobb, 1898 , primarily a parasite of domestic sheep, Ovis aries, also infects numerous other domestic and wild ruminants.

Haemonchus placei (Place, 1893) Ransom, 1911 , is primarily a parasite of domestic cattle (Bos taurus) but it has been found also in domestic sheep, white-tail deer (Odocoileus virginianus), and pronghorn antelope (Antilocapra americana). Haemonchus placei is not universally accepted as a separate species (Gibbons, 1979). However, Lichtenfels et al. (1986) described differences between $H$. place $i$ and $H$. contortus in the percentage of the body covered by the synlophe, which made it possible to identify most populations to species if at least 10 specimens are examined. This paper describes newly

Received 2 April 1993; revised 10 September 1993; accepted 10 September 1993. recognized features of the synlophe that can be used to determine the species of individual specimens of either sex of $H$. contortus and $H$. placei.

The third species of the genus Haemonchus parasitic in North American ruminants is $H$. similis Travassos, 1914. This species has been reported in domestic cattle in a few southern states of the U.S.A., Central and South America, Asia, and several Atlantic and Pacific islands (Donald, 1963), in Bos indicus in Tanzania and Uganda (Gibbons, 1979), domestic sheep in Brazil (Lins de Almeida, 1935), white-tail deer in Florida (Dinaburg, 1939), and in numerous other ruminants and localities (Doss et al., 1985). In addition to differences in the synlophe, distinctive characteristics of the spicules, female reproductive tract, and female tail allow $H$. similis to be separated from both $H$. contortus and $H$. placei.

An illustrated, dichotomous key to males and females of $H$. contortus, $H$. placei, and $H$. similis is presented. This key makes it possible to identify individual specimens of all 3 species of large stomach worms present in North American ruminants.

Seven additional species of Haemonchus (review by Gibbons, 1979) that parasitize wild ruminants of Africa and/or the camel (Dutt and Sahai, 1966) were not included in the present study.

\section{MATERIALS AND METHODS}

A list of nematodes studied is presented (Table I) including host names, geographic localities, number of 
TABLE I. Specimens of Haemonchus spp. studied by nematode species, host species, locality, and nematode sex.

\begin{tabular}{|c|c|c|c|c|c|}
\hline \multirow{2}{*}{$\begin{array}{l}\text { Collection } \\
\text { number* }\end{array}$} & \multirow[b]{2}{*}{ Species } & \multirow[b]{2}{*}{ Host } & \multirow[b]{2}{*}{ Locality } & \multicolumn{2}{|c|}{ Number studied } \\
\hline & & & & Male & Female \\
\hline 39960 & Haemonchus contortus & Ovis aries & Florida & 1 & 2 \\
\hline 64756 & H. contortus & $O$. aries & Georgia & 0 & 1 \\
\hline 70001 & H. contortus & $O$. aries & Georgia & 5 & 5 \\
\hline 33156 & H. contortus & $O$. aries & Maine & 4 & 4 \\
\hline 69990 & H. contortus & $O$. aries & Maryland & 1 & 2 \\
\hline $70404 \dagger$ & H. contortus & O. aries & Michigan & 5 & 5 \\
\hline $70405 \ddagger$ & H. contortus & O. aries & Michigan & 5 & 5 \\
\hline $70406 \S$ & H. contortus & $O$. aries & Michigan & 5 & 5 \\
\hline 47825 & H. contortus & O. aries & Nebraska & 4 & 4 \\
\hline 40172 & H. contortus & $O$. aries & North Caroina & 5 & 4 \\
\hline 40659 & H. contortus & $O$. aries & Texas & 1 & 0 \\
\hline$\|$ & H. contortus & $O$. aries & Texas & 0 & 3 \\
\hline$\|$ & H. contortus & O. aries & Texas & 1 & 1 \\
\hline$\|$ & H. contortus & O. aries & Texas & 0 & 1 \\
\hline$\|$ & H. contortus & $O$. aries & Texas & 2 & 2 \\
\hline 58830 & H. contortus & $O$. aries & Vermont & 0 & 5 \\
\hline 56711 & H. contortus & 0. aries & West Virginia & 3 & 1 \\
\hline 69996 & H. contortus & $O$. aries & Australia & 2 & 1 \\
\hline 81048 & H. contortus & $O$. aries & Brazil & 5 & 5 \\
\hline \# & H. contortus & $O$. aries & South Africa & 12 & 10 \\
\hline 70374 & H. contortus & Bos taurus & Maryland & 25 & 25 \\
\hline 67080 & H. contortus & Capra hircus & Sierra Leone & 1 & 4 \\
\hline 67185 & H. contortus & Odocoileus virginianus & Oklahoma & 2 & 2 \\
\hline $66540 \pi$ & H. contortus & O. virginianus & Texas & 6 & 0 \\
\hline $32146^{* *}$ & H. contortus & Ovibos moschatus & Washington, D.C. & 5 & 2 \\
\hline 70277 & H. contortus & Pelea capreolus & South Africa & 5 & 5 \\
\hline 70276 & H. contortus & Redunca redunca & South Africa & 5 & 5 \\
\hline $66649 \pi$ & H. contortus & Syncerus caffer & Uganda & 3 & 3 \\
\hline 39902 & Haemonchus placei & B. taurus & Florida & 2 & 1 \\
\hline 69986 & H. placei & B. taurus & Florida & 5 & 0 \\
\hline 70247 & H. placei & B. taurus & Florida & 3 & 2 \\
\hline 49243 & H. placei & B. taurus & Hawaii & 0 & 5 \\
\hline 69987 & H. placei & B. taurus & Louisiana & 5 & 5 \\
\hline 70382 & H. placei & B. taurus & Louisiana & 16 & 10 \\
\hline 47217 & H. placei & B. taurus & Louisiana & 4 & 6 \\
\hline 58800 & H. placei & B. taurus & Louisiana & 3 & 0 \\
\hline 29346 & H. placei & B. taurus & Maryland & 3 & 5 \\
\hline $70324+\dagger$ & H. placei & B. taurus & Maryland & 0 & 1 \\
\hline $70372+1$ & H. placei & B. taurus & Maryland & 20 & 11 \\
\hline $70373+t$ & H. placei & B. taurus & Maryland & 10 & 10 \\
\hline $70375+\dagger$ & H. placei & B. taurus & Maryland & 5 & 5 \\
\hline 70377 & H. placei & B. taurus & Maryland & 6 & 6 \\
\hline $70385+\dagger$ & H. placei & B. taurus & Maryland & 0 & 1 \\
\hline 19472 & H. placei & B. taurus & Mississippi & 4 & 5 \\
\hline 70138 & H. placei & B. taurus & New Jersey & 2 & 1 \\
\hline$\|$ & H. placei & B. taurus & Texas & 3 & 0 \\
\hline 59090 & H. placei & B. taurus & Guyana & 3 & 3 \\
\hline 70402 & H. placei & B. taurus & South Africa & 8 & 6 \\
\hline $66540 \pi$ & H. placei & O. virginianus & Texas & 1 & 2 \\
\hline$\|$ & H. placei & $O$. aries & Texas & 0 & 1 \\
\hline 69995 & H. placei & $O$. aries & Australia & 5 & 5 \\
\hline 43625 & Haemonchus similis & O. virginianus & Florida & 1 & 0 \\
\hline 34073 & H. similis & B. taurus & Florida & 0 & 4 \\
\hline 39902 & H. similis & B. taurus & Florida & 9 & 4 \\
\hline 70247 & H. similis & B. taurus & Florida & 1 & 2 \\
\hline $70301+t$ & H. similis & B. taurus & Maryland & 7 & 5 \\
\hline $70324+t$ & H. similis & B. taurus & Maryland & 8 & 2 \\
\hline $70375+\dagger$ & H. similis & B. taurus & Maryland & 0 & 2 \\
\hline $70385+t$ & H. similis & B. taurus & Maryland & 20 & 1 \\
\hline 45184 & H. similis & B. taurus & North Carolina & 0 & 3 \\
\hline 29412 & H. similis & B. taurus & Puerto Rico & 2 & 2 \\
\hline 29462 & H. similis & B. taurus & Texas & 1 & 2 \\
\hline 59091 & H. similis & B. taurus & Guyana & 3 & 3 \\
\hline 66648 & H. similis & Bos indicus & Uganda & 3 & 3 \\
\hline
\end{tabular}

* Collection numbers of specimens deposited in the U.S. National Parasite Collection.

† Susceptible strain from G. A. Conder, Kalamazoo, Michigan. 


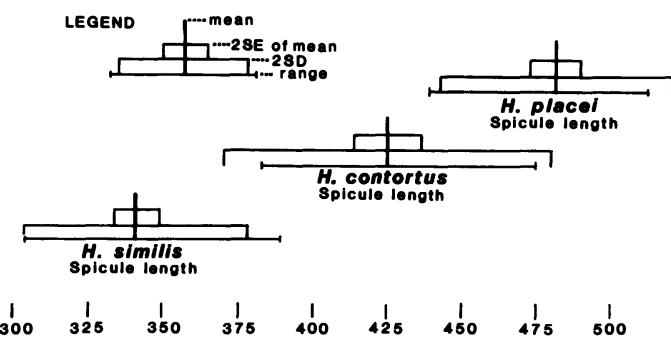

FIGURE 1. Spicule lengths (from data in Table II) of 3 species of Haemonchus with $95 \%$ confidence bands for mean $( \pm 2 \mathrm{SE})$ and population $( \pm 2 \mathrm{SD})$.

specimens examined, and collection numbers of specimens deposited in the U.S. National Parasite Collection (USDA, ARS, BARC-East, Bldg. No. 1180, Beltsville, Maryland). Frozen specimens from T. M. Craig were used (Zarlenga et al., 1994) in DNA studies and therefore not deposited. Specimens from South Africa loaned for study by J. A. van Wyk were returned to him.

Whole specimens were cleared in phenol-alcohol (80 parts melted phenol crystals and 20 parts absolute ethanol) and studied in temporary mounts. Interferencecontrast light microscopy was used to study the synlophe and other characters at a magnification of $400 \times$. Frozen specimens can be studied in water. Living specimens should be studied in saline, and the coverglass should be supported by glass beads if the viability of the specimen is to be preserved. We have not tested the viability of such specimens.

Cross sections were studied as either freehand cuts made with a cataract knife and mounted in glycerine jelly or in paraffin-embedded sections cut at $5 \mu \mathrm{m}$ with a microtome and stained in hematoxylin and eosin. Measurements of specimens were obtained with the aid of a calibrated ocular micrometer on a compound microscope and are recorded in micrometers unless indicated otherwise. Drawings of the synlophes were prepared free-hand while viewing the specimens at a magnification of $400 \times$.

The description of the ovejectors follows the detailed description of the ovejectors of $H$. contortus by Veglia (1915). The terminology of Veglia (1915) is modified as follows. The elongate cylindrical sphincters of Strongyloidea (see Lichtenfels, 1980) are homologous to the pars ejectrix of Veglia (1915). The anterior portion of the pars ejectrix of Haemonchus spp. is sphincter-

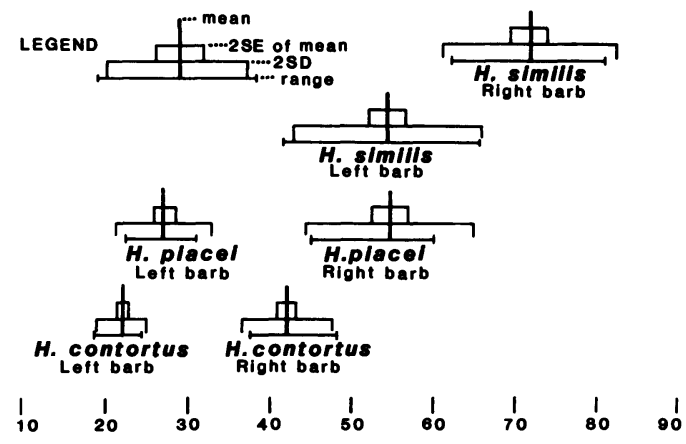

FIGURE 2. Distances (from data in Table II) from spicule barbs to distal tips of spicules of 3 species of Haemonchus with $95 \%$ confidence bands for mean $( \pm 2$ $\mathrm{SE})$ and population ( \pm 2 SD). See also Figures 10-12.

shaped, but the pars ejectrix also includes a cylindrical part that is clearly distinguishable from the thinnerwalled vestibule (Figs. 13-15). The infundibulum is equivalent to the pars haustrix of Veglia (1915).

Populations of nematodes were identified to species as follows: $\boldsymbol{H}$. similis were distinguished from $\boldsymbol{H}$. contortus and $H$. placei on the basis of spicular structure and length, and vulvar structure and tail length. Then $H$. contortus and $H$. place $i$ were separated on the basis of spicule lengths (Lichtenfels et al., 1988) or on the percentage of the body bearing the longitudinal surface cuticular ridges of the synlophe (percentage of total

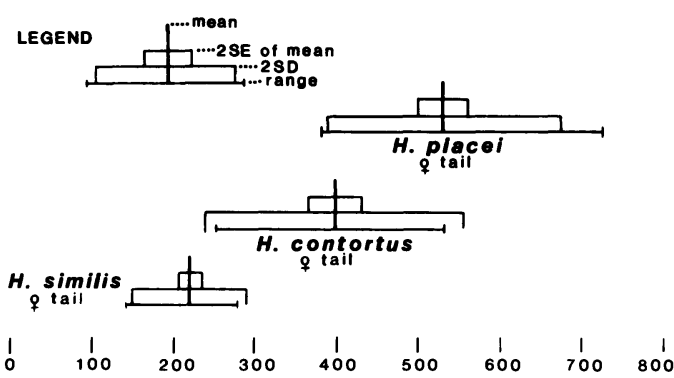

FIGURE 3. Tail lengths (from data in Table III) of females of 3 species of Haemonchus with $95 \%$ confidence bands for mean $( \pm 2 \mathrm{SE})$ and population $( \pm 2$ SD). See also Figures 16-18.

$\ddagger$ Ivermectin/benzimidazole-resistant strain from G. A. Conder, Kalamazoo, Michigan.

$\S$ Levamisole/benzimidazole-resistant strain from G. A. Conder, Kalamazoo, Michigan

\| All specimens (6 lots) from T. M. Craig, Texas. (1) from Uvalde County, ivermectin/levamisole resistant; (2) original host Addax nasomaculata, with experimental infections in lambs; (3) from the Craig ranch; (4) from east Texas, original host Capra hircus with experimental infection in lambs, benzimidazole/ivermectin resistant; (5) from Brazos County, raised in cattle; (6) from Boerne, Kendall County. Sheep grazed on pasture with exotic antelope.

\# Specimens from sheep in South Africa from J. A. van Wyk.

I Possible hybrid specimens; short or intermittent subventral and subdorsal ridges.

** Specimens from a National Zoological Park animal. Original locality unknown.

†† Experimental infections in calves in Maryland, originally from tracer calves in Florida. 

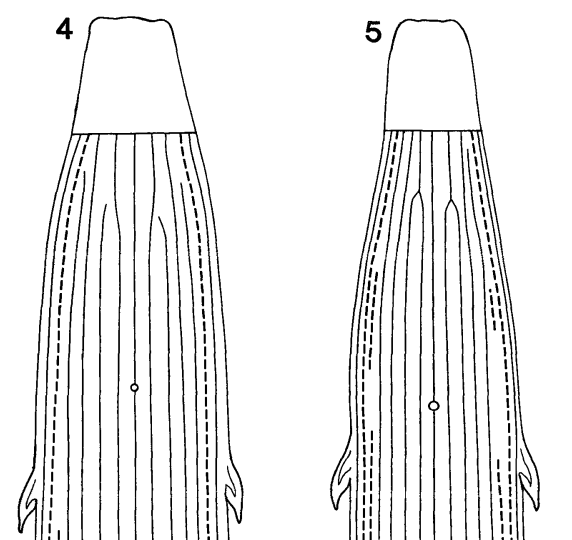

(1)

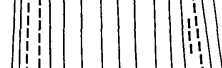

(1)

(1)

\begin{tabular}{ll|l}
1 \\
1 \\
1 \\
1
\end{tabular}

:

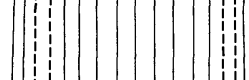

1

1: 10

1 10

1

1 10

(1)

1 10

1

1

$\left(\begin{array}{l}1 \\ 1 \\ 1 \\ 1 \\ 1 \\ 1 \\ 1 \\ 1 \\ 1 \\ 1 \\ 1 \\ 1 \\ 1 \\ 1 \\ 1 \\ 1 \\ 1\end{array}\right)$

:

:

$\left.\| \begin{array}{l}1 \\ 1 \\ 1 \\ 1 \\ 1\end{array}\right)\|\|$
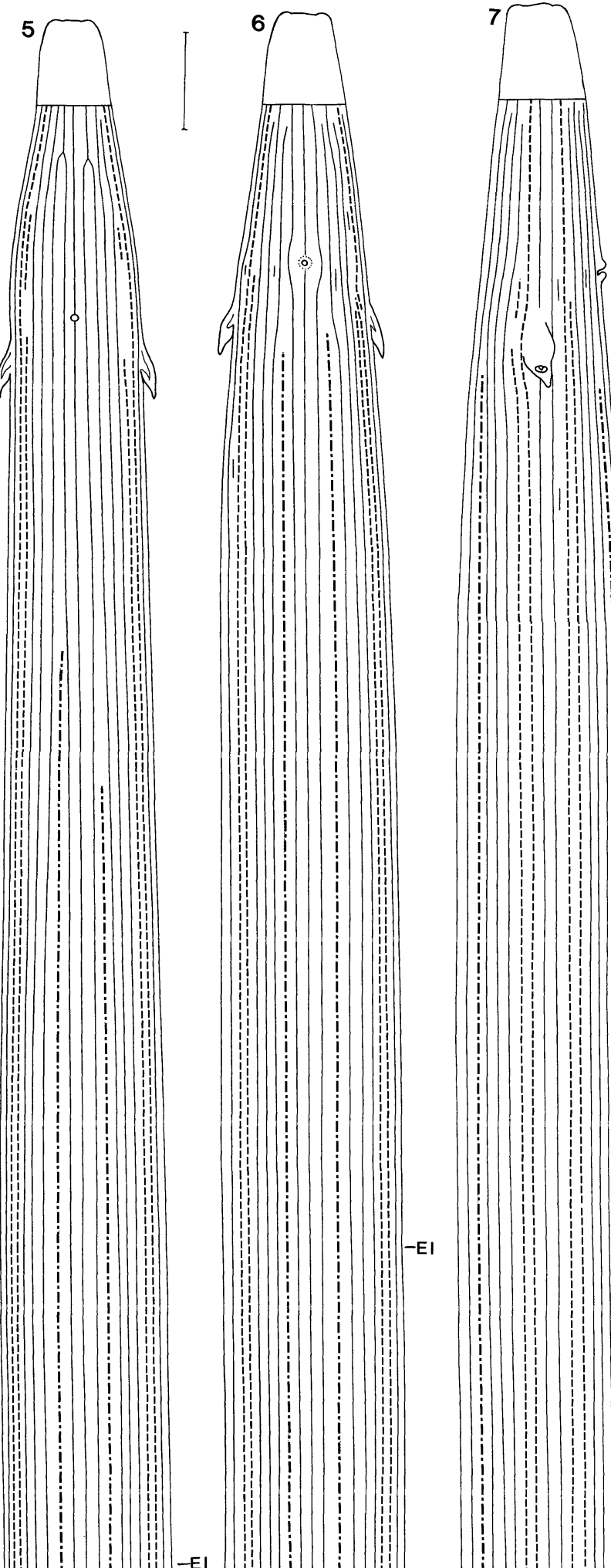

i

III

i)

i)

i

i

!)

i)

!)

i)

i

!)

i

i

i

i

a

i 1

a

i

!

i

i)

a

i

1 1 1 i

i 1 (1)

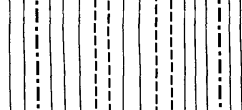

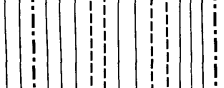

(1)

i.

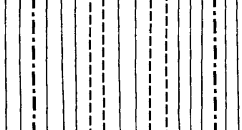


length in males and percentage of prevulvar length in females) (Lichtenfels et al., 1986). Specimens previously identified in the cited earlier studies were used when possible. The numbers of specimens listed in Table I are those used to evaluate the newly described synlophe characteristics.

Samples were selected to represent as wide a geographic and host range as possible. Measurements were made of a few specimens from each of a large number of individual hosts because variation among samples from individual hosts was expected to be greater than variation within one sample (Lichtenfels, unpubl. data). Observed differences in size of various structures among the 3 species (Tables II, III) were compared statistically by calculating $95 \%$ confidence bands for the samples $( \pm 2 \mathrm{SD})$ and for the sample means $( \pm 2 \mathrm{SE}$ ) (Steel and Torrie, 1960). The results were illustrated graphically (Figs. 1-3) as described by Lichtenfels et al. (1988).

\section{RESULTS}

\section{Size differences}

Morphometrics of $H$. contortus, $H$. placei, and $H$. similis are given by sex in Table II (males) and Table III (females). Among males of the 3 species, the most useful size differences are spicule lengths (Fig. 1) and distances of the barbs from the distal end (Fig. 2). Figure 1 shows that the mean spicule lengths of all 3 species differ significantly from each other $(95 \%$ confidence level), but that overlapping ranges of spicule lengths prevent identification of individual specimens. The relative position of the distal barbs of the spicules (Figs. 2, 10-12) of $H$. similis can be used to distinguish unequivocally males of this species from those of $H$. contortus and $H$. placei. Of the 3 species, only in $H$. similis are the barbs of both the left and right spicules greater than $10 \%$ of the spicule length from the distal tips. The barb of the left spicule of $H$. similis is significantly farther (20-21\% of spicule length) from the distal tip than in the other 2 species (both about 11\%). The barb of the right spicule of $H$. similis is significantly farther from the distal tip (13-17\% of spicule length) than in $H$. contortus and $H$. placei (both about $5 \%$ of spicule length), but the difference in range of measurements between $H$. similis and $H$. placei (Fig. 2) is not statistically significant (see overlapping bars for 2 SD). Thus, the barbs of the right spicules of $H$. place $i$ and $H$. similis can be distinguished by the percentage of total length from the distal tip to the barb but not by actual measurements because of the significantly greater spicule lengths (Fig. 1) of the latter species. The means of the distances from spicule barb to distal tip can also be used to separate $H$. place $i$ and $H$. contortus males, but the overlapping ranges of measurements prevent the use of this character for identification of individual males of these species.

Females of $H$. similis can be distinguished from those of $H$. placei by their significantly shorter tail length (Figs. 3, 16-18; Table III); and most specimens of $H$. similis can be distinguished from both $H$. place $i$ and $H$. contortus by the presence of a longer vagina (Table III) that usually extends into a vulval flap and opens in the flap (Fig. 15) rather than on or near the body wall as in the other 2 species (Figs. 13, 14).

\section{Synlophe}

The synlophe in all 3 species is bilaterally and dorsoventrally symmetrical with the result that left and right, and also dorsal and ventral halves, are mirror images of each other. There is no ridge at the lateral line so each of the 30 or 34 ridges is in either the dorsal or ventral field (Figs. 4-7). In all 3 species the third ridge from the lateral chord both dorsally and ventrally is shorter than adjacent ridges and usually extends anteriorly only to the level of the cervical papillae, although in some specimens it ends well anterior to the excretory pore.

Both $H$. similis and $H$. placei bear 17 dorsal and 17 ventral (total 34) longitudinal cuticular ridges in the region of the posterior half of the esophagus (Figs. 5-7, 23, 27). In $H$. contortus,

FIGURES 4-7. Diagrammatic drawings of the anterior ends of 3 species of Haemonchus showing the synlophe patterns in the region of the esophagus (dashed lines, sublateral ridges; dot-dash lines, subventral or subdorsal ridges; EI, esophageal-intestinal junction) (scale bar $=100 \mu \mathrm{m}$ ). Note that in ventral views (Figs. 4-6) because there are no lateral ridges dividing ventral and dorsal fields, the lateralmost lines in these figures represent the lateralmost ridges of the dorsal field. 4. Anterior synlophe of $H$. contortus, ventral view, showing 17 of 30 ridges at EI. Note absence of subventral ridges. 5. Anterior synlophe of $H$. placei, ventral view, showing 19 of 34 ridges at EI. Note presence of subventral ridges. 6. Anterior synlophe of $H$. similis, ventral view, showing 19 of 34 ridges at EI. Note presence of subventral ridges. 7. Lateral view of $H$. similis showing one ridge of each pair of subdorsal and subventral ridges, which are present in $H$. similis and in $H$. placei. 


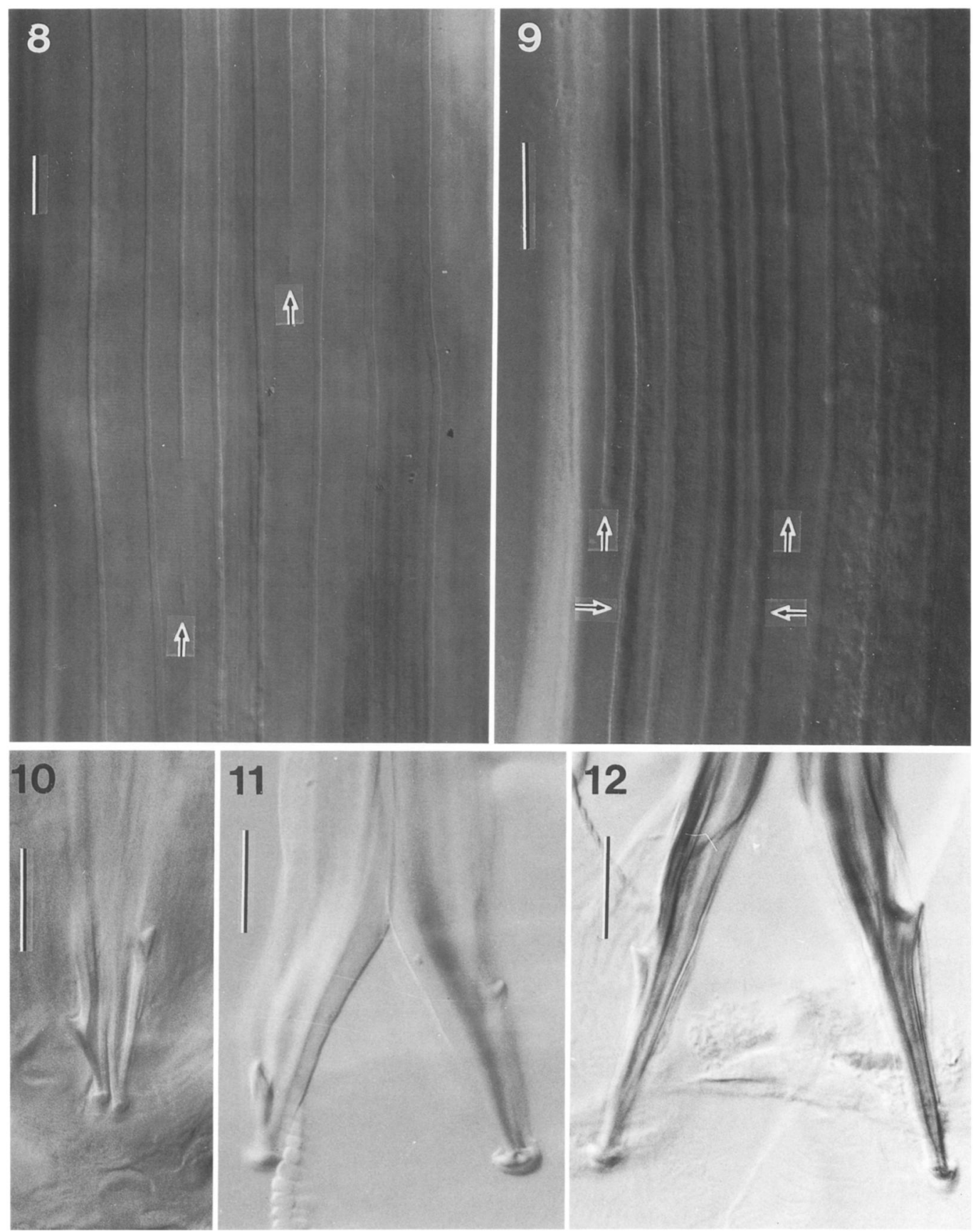

FIGURES 8-12. Lateral synlophe patterns and spicule tips of 3 species of Haemonchus (scale bars $=25 \mu \mathrm{m}$ ). 8. Lateral synlophe of $H$. contortus showing distal ends (arrows) of more lateral of the sublateral ridges ending next to paired lateralmost ridges. 9. Lateral synlophe of $H$. similis showing distal ends (vertical arrows) more dorsal and ventral of sublateral ridges adjacent to more lateral pair of sublateral ridges (horizontal arrows) adjacent to paired lateralmost ridges. 10. Spicule tips of $H$. contortus. 11. Spicule tips of H. placei. 12. Spicule tips of $H$. similis. 
TABLE II. Morphometrics of Haemonchus spp. males.*

\begin{tabular}{|c|c|c|c|}
\hline Character & $\begin{array}{l}\text { Haemonchus } \\
\text { contortus }\end{array}$ & $\begin{array}{c}\text { Haemonchus } \\
\text { placei }\end{array}$ & $\begin{array}{l}\text { Haemonchus } \\
\text { similis }\end{array}$ \\
\hline Number examined & 23 & 21 & 24 \\
\hline Body length (mm) & $11.0-17.0(13.1)$ & $10.9-18.9(14.4)$ & $7.3-10.1(8.8) \dagger$ \\
\hline Nerve ring $\ddagger$ & $188-326(254)$ & $235-319(287)$ & $210-244(228)$ \\
\hline Excretory pore $\ddagger$ & $232-356(285)$ & $266-367(321)$ & $225-274(246)$ \\
\hline Cervical papillaeł & $271-462(354)$ & $351-440(403)$ & $281-353(312)$ \\
\hline Subventral esophageal gland orificesł & $356-626(493)$ & $506-668(587)$ & $394-506$ (448) \\
\hline Esophagus length $(\mathrm{mm})$ & $1.09-1.55(1.26)$ & $1.31-1.74(1.48)$ & $0.82-1.28(1.10)$ \\
\hline Esophagus as percentage of body length & $8.0-11.2(9.8)$ & $8.6-12.1(10.4)$ & $9.9-14.8(12.6)$ \\
\hline Gubernaculum length & $195-255(221)$ & $210-270(245)$ & $142-198(179) \dagger$ \\
\hline Spicule length & $383-475(425)$ & $438-511(481)$ & $304-389(341) \dagger$ \\
\hline Spicule barb length right/left & $37-48 \quad(42) / 19-24(22)$ & $45-60 \quad(55) / 22-32(27)$ & $62-81 \quad(71) \dagger / 41-65(54) \dagger$ \\
\hline
\end{tabular}

* Measurements (in micrometers unless noted otherwise) are ranges followed by means in parentheses.

$\dagger$ Measurements that differ significantly ( $95 \%$ confidence) from those of at least 1 of the other 2 species.

$\ddagger$ Measured from anterior extremity.

TABLE III. Morphometrics of Haemonchus spp. females.*

\begin{tabular}{|c|c|c|c|}
\hline Character & $\begin{array}{l}\text { Haemonchus } \\
\text { contortus }\end{array}$ & $\underset{\text { placei }}{\text { Haemonchus }}$ & $\begin{array}{l}\text { Haemonchus } \\
\text { similis }\end{array}$ \\
\hline Number measured & 22 & 21 & 26 \\
\hline Body length (mm) & $14.8-27.2(18.5)$ & $12.5-25.5(19.6)$ & $10.4-17.0(13.4)$ \\
\hline Nerve ring $\dagger$ & 210-394 (271)‡ & $225-330(290)$ & $165-300(229)$ \\
\hline Excretory pore $\dagger$ & $205-400(290)$ & $281-379$ & $188-289(246)$ \\
\hline Cervical papillae $\dagger$ & $243-484$ (363) & $359-460(414)$ & $233-379(313)$ \\
\hline Subventral esophageal gland orifices $\dagger$ & $435-656(525) \ddagger$ & $540-728(623)$ & $443-564(500)$ \\
\hline Esophagus length (mm) $\dagger$ & $1.15-1.66(1.38)$ & $1.38-1.84(1.60)$ & $1.09-1.42(1.25)$ \\
\hline Esophagus as percentage of body length & $5.8-8.9 \quad(7.6)$ & $6.7-11.1(8.3)$ & $7.8-11.5(9.5)$ \\
\hline Vulva position (percentage) $\dagger$ & $76.3-84.8(82.4)$ & $74-84 \quad(81)$ & $75.6-89.1(81.7)$ \\
\hline Anterior infundibulum length & $188-394(272)$ & $188-461(290)$ & $149-319(204)$ \\
\hline Anterior spincter length & $154-284(222)$ & $191-356(244)$ & $124-249(184) \|^{* *}$ \\
\hline Vestibula length & $150-263(198)$ & $225-356(261)$ & - \\
\hline Vagina length & $75-188(110)$ & $75-131$ (104)\# & 161-300 (217) थ†† \\
\hline Posterior sphincter length & $158-266(227)$ & $182-330(245) \ddagger$ & $143-300(216) \|$ \\
\hline Posterior infundibulum length & $169-341(277) \S$ & $240-441(306)$ & $152-300(205) \|$ \\
\hline Tail length & $251-530(396)$ & $378-720(527)$ & 135-278 (219)†† \\
\hline Phasmids (right/left) $\ddagger \ddagger$ & $86-235(143) / 84-249(143)$ & $122-239(167) / 125-239(171)$ & $52-93 \quad(74) \S+\dagger / 60-93(77) \dagger \dagger$ \\
\hline
\end{tabular}

* Measurements (in micrometers unless noted otherwise) are ranges followed by means in parentheses.

$\dagger$ Measured from anterior extremity.

$\ddagger \mathrm{n}=20$.

$\S \mathrm{n}=21$.

$\| \mathrm{n}=22$.

$\# \mathrm{n}=19$.

I $\mathrm{n}=24$.

** Measurement includes vestibula length

$+\dagger$ Measurements that differ significantly ( $95 \%$ confidence) from at least 1 of the other 2 species.

拉 Distance from distal tip of tail.

there are only 15 ridges dorsally and 15 ventrally (total 30) (Figs. 4, 19). This number was constant in both males and females in all lots that were studied, but minor variations were frequently observed due to either the presence of short extra ridges in atypical locations (Figs. 6, 7) or crossovers where one ridge reversed positions with an adjacent ridge.

Two of the 4 additional ridges present in $H$. similis and $H$. placei are illustrated as dot-dash lines in Figures 5 and 6 . They are situated 1 on each side of the 3 ventralmost ridges and are herein referred to as subventral ridges. There are also 2 similar "subdorsal" ridges in an equivalent position, subdorsally in these 2 species. The subventral and subdorsal ridges usually extend anteriorly only to a level equal to the middle third of the esophagus but more rarely as far anteriorly as the cervical papillae or excretory pore. They are continuous for most of their length but may be interrupted near their anterior and posterior ends. Haemonchus placei differs from $H$. similis in that the subventral and subdorsal ridges of the former extend posteriorly for 4-5 $\mathrm{mm}$ and end 

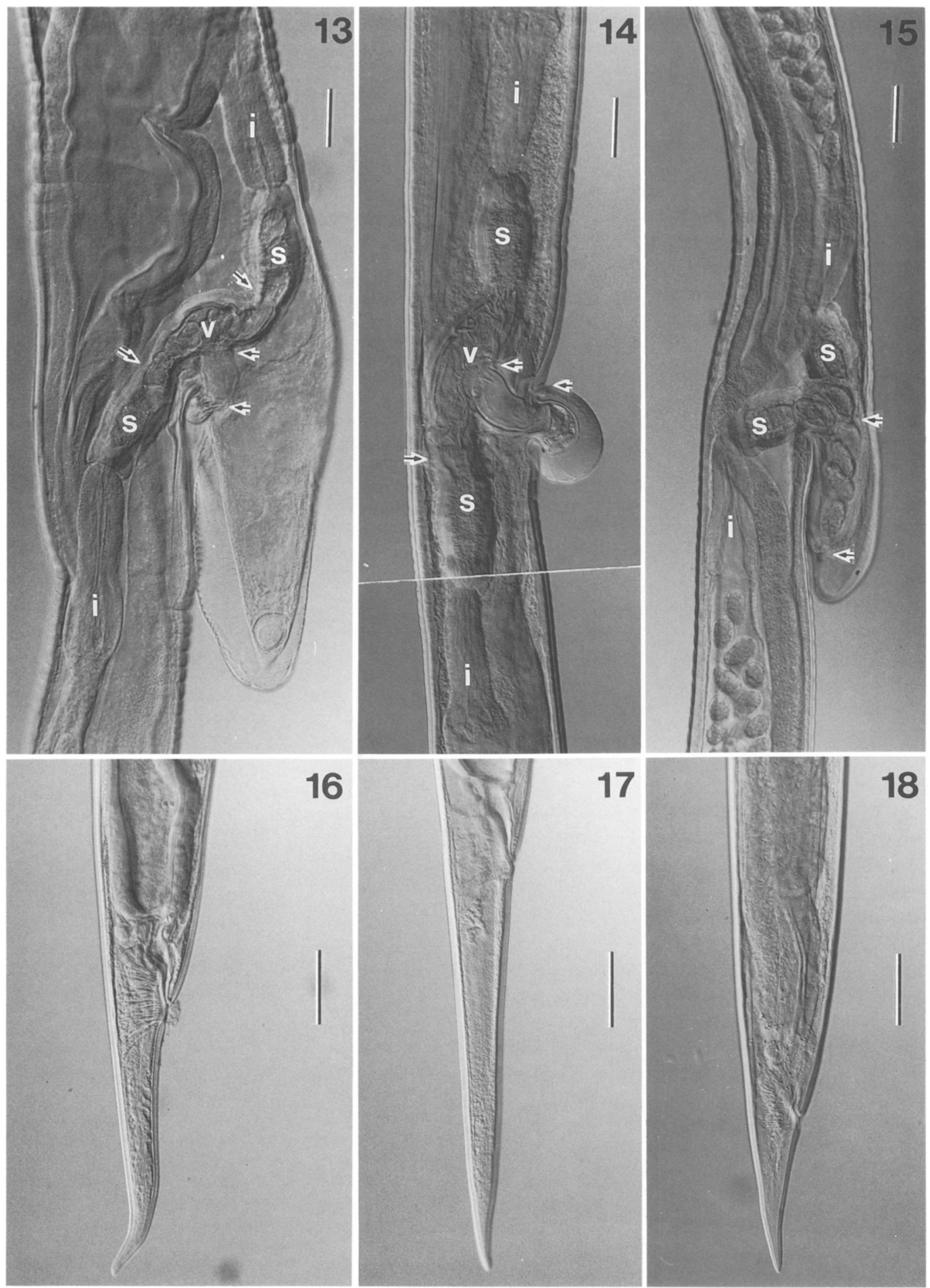

FIGURES 13-18. Paired, opposed ovejectors and tails of females of 3 species of Haemonchus (i, infundibula; s, sphincters; v, vestibule; arrows, both ends of vagina and at junction of sphincters and vestibule) (scale bars $=100 \mu \mathrm{m})$. Note that variation in the anatomy of vulval lobes within species is high and is not a reliable character for identifying species. 13. Ovejectors of $H$. contortus with large lobe over vulva. 14. Ovejectors of $H$. 
near the middle of the length of the synlophe (about one-fourth of the length of the nematode from the anterior end), but in $H$. similis the subventrals and subdorsals extend to the end of the synlophe, which is near midbody.

The synlophe of experimentally produced hybrids (Lichtenfels et al., 1986) from matings of $H$. contortus and $H$. place in sheep have an intermediate pattern of subventral ridges. When the 2 subventral and 2 subdorsal ridges were present they were much shorter than in $H$. placei and usually the subdorsals and subventrals were absent on either the left or right side.

A single lot of specimens identified as $H$. contortus (No. 70404) had traces of subdorsal and subventral ridges, but they were short (usually less than $1 \mathrm{~mm}$ in length) and were not present in all 4 usual locations.

In the anterior half of the body of all 3 species, 4 pairs of ridges (illustrated as dashed lines in Figs. 4-7) occur parallel to the lateralmost ridges (and are herein named the sublateral ridges). Posteriorly in all 3 species the sublateral ridges disappear at 2 different levels, 2 pairs ( 1 pair on the left and 1 pair on the right) at about the middle of the length of the synlophe and the second 2 pairs more or less near the end of the synlophe. Because the pairs of sublateral ridges may not end posteriorly in a completely symmetrical pattern (left pair may extend slightly longer than corresponding pair on the right, and/or ventral of pair may extend further than dorsal of pair) and because the ridges frequently end by becoming discontinuous, it is difficult to find a perfectly symmetrical cross section showing the standard number of sublateral ridges. In $H$. contortus the number of ridges is reduced from 30 to 26 (see 25 ridges in Fig. 20) 3-4 mm from the anterior end and from 26 to $225-6 \mathrm{~mm}$ from the anterior end and $2-3 \mathrm{~mm}$ anterior to the end of the synlophe (Figs. 21, 22). Haemonchus placei loses the first 2 pairs of sublateral ridges $3-4 \mathrm{~mm}$ from the anterior end, reducing the number from 34 (Fig. 23) to 30 (Fig. 24); loses the 2 subdorsals and 2 subventrals 4-6 $\mathrm{mm}$ from the anterior end, reducing the number to 26 (see 25 ridges in Fig. 25); and loses the second 2 pairs of sublaterals $0.1-0.5 \mathrm{~mm}$ anterior to the end of the synlophe in males and $0.7-2.2 \mathrm{~mm}$ from the end of the synlophe in females, reducing the number of ridges to 22 (Fig. 26). In $H$. similis the number of ridges is reduced by 4 twice: from 34 (Fig. 27) to 30 near the middle of the synlophe (3-4 mm from the anterior end) (Figs. 28, 29) and then to 26 (Fig. 30) $2-3 \mathrm{~mm}$ anterior to the end of the synlophe in females and near the end of the synlophe in males.

In both $H$. placei and $H$. contortus, the sublateral ridges next to the lateral most ridges end posteriorly first (Fig. 8), before the more dorsal and ventral of the sublaterals end, but the situation is reversed in $H$. similis (Fig. 9).

\section{Key to species}

The characters described above were used to construct an identification key to both males and females of the 3 species of Haemonchus parasitic in domesticated ruminants. Hybrids between $H$. contortus $\times H$. place $i$ have characteristics that are intermediate between the 2 species (Lichtenfels, unpubl. data). For a discussion of the use of spicule lengths to identify species, see Lichtenfels et al. (1988).

1a. Male specimens $\ldots \ldots \ldots \ldots \ldots \ldots 2$

1b. Female specimens . ........... 4

2a. Spicule length about 300-400 $\mu \mathrm{m}$ (Fig. 1) and barbs of spicules near distal ends relatively distant from distal tips (right 62-81, left 41-65; about 20 and $15 \%$ of spicule lengths, respectively) and right and left barbs in nearly symmetrical positions (Figs. 2,12) .............. Haemonchus similis

2b. Spicule lengths about 400-500 $\mu \mathrm{m}$ (Fig. 1); and barbs of spicules near distal ends relatively close to tips with right barb about twice as far from tip (37-60 $\mu \mathrm{m})$ as the left barb (19-32 $\mu \mathrm{m}$ ) (about 11 and $5 \%$ of spicule lengths, respectively) (Figs. 2, 10, 11) . . 3

3a. Mean spicule length of 10 specimens greater than $450 \mu \mathrm{m}$; or, synlophe with subventral and subdorsal ridges (Fig. 5) that begin in region of esophagus and extend posteriorly 3-5 mm ........... Haemonchus placei

3b. Mean spicule length (of 10 or more random specimens) significantly less than $450 \mu \mathrm{m}$; or synlophe without subventral or subdorsal

place $i$ with vulva anterior to protruding knob. 15. Ovejectors of $H$. similis with small vestibule between sphincters and the long vagina extending to the vulva near the distal end of the long lobe. 16. Tail of $H$. contortus female. (Note: dorsal curvature of tail is of no significance.) 17. Tail of $H$. placei female. 18. Tail of $H$. similis female. 

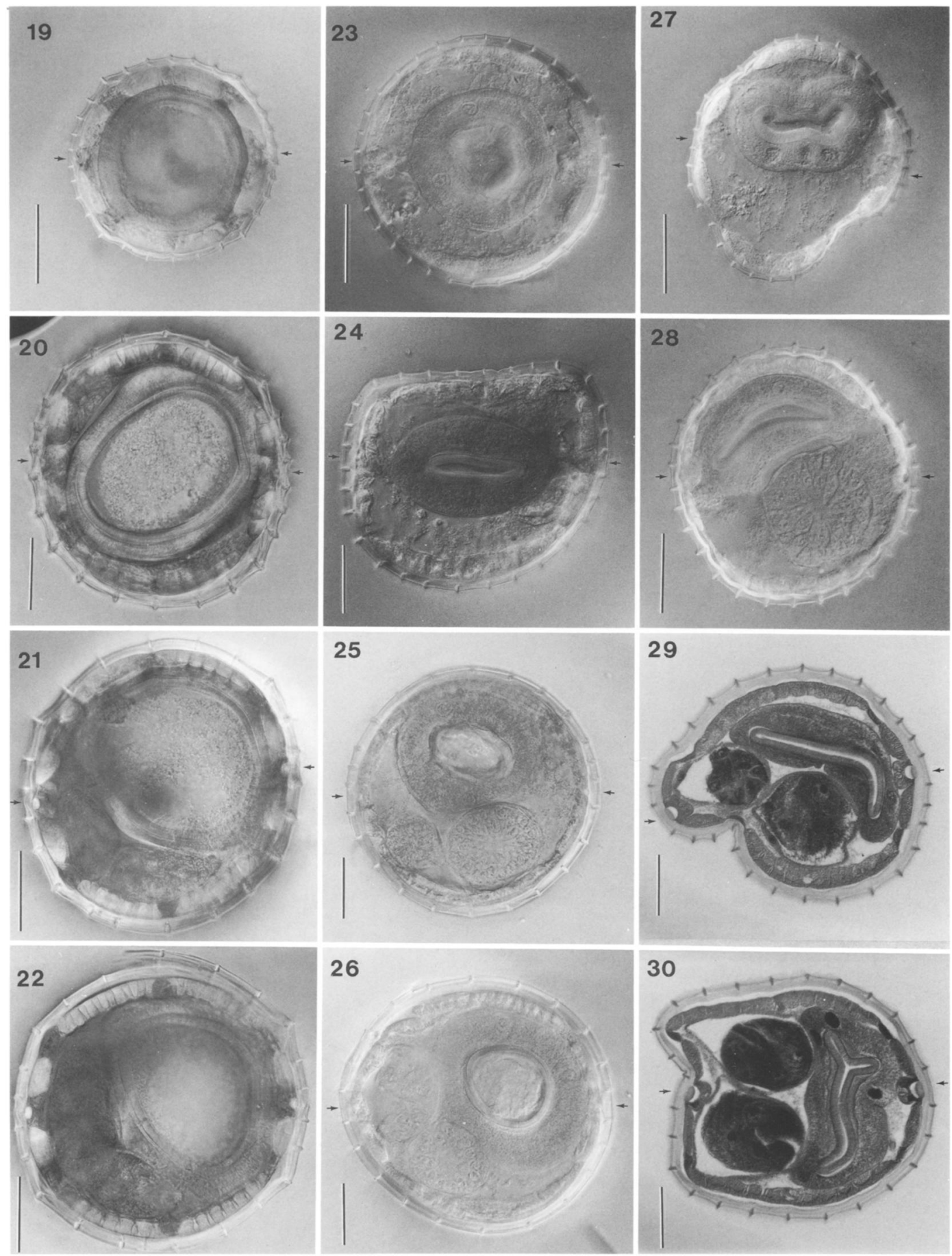

Figures 19-30. Cross sections of female specimens of 3 species of Haemonchus at 4 comparable body locations to show the number and structure of the ridges of the synlophe (arrows at lateral lines) (scale bars $=$ $50 \mu \mathrm{m})$. 19. H. contortus, at esophageal-intestinal (EI) junction, showing 30 ridges. 20. Haemonchus contortus, $4 \mathrm{~mm}$ from anterior end, showing 25 ridges. 21. Haemonchus contortus, $6 \mathrm{~mm}$ from anterior end, showing 22 ridges. 22. Haemonchus contortus, near midbody, showing 22 ridges. 23. Haemonchus placei, at EI, showing 34 ridges. 24. Haemonchus placei, $4 \mathrm{~mm}$ from anterior end, showing 30 ridges. 25. Haemonchus placei, $6 \mathrm{~mm}$ from 
ridges (Fig. 4) or with only a trace of 1 or 2 of them ......... Haemonchus contortus

4a. Synlophe without subventral or subdorsal ridges (Fig. 4) or with only a trace of 1 or 2 of them ......... Haemonchus contortus

4b. Synlophe with subventral and subdorsal ridges (Figs. 5, 6) that extend posteriorly from the midlength of the esophagus for several millimeters or more ............. 5

5a. Tail short (135-278 $\mu \mathrm{m}$ ) and conical (Fig. 18); vulva usually in vulval lobe distant from body wall (Fig. 15); subventral and subdorsal ridges extend to posterior end of synlophe ........... Haemonchus similis

5b. Tail long (378-720 $\mu \mathrm{m})$ and almost filiform (Fig. 17); vulva flush with body wall (Fig. 14); subventral and subdorsal ridges extend posteriorly for about one-half the length of the synlophe .......Haemonchus place $i$

\section{DISCUSSION}

This report presents newly recognized characteristics of the 3 common large stomach worms of ruminants of North America that make it possible, for the first time, to identify individual intact, whole adult specimens to species. The characters useful for identifying individuals can be determined in fixed and cleared, living or freshly thawed frozen specimens at $400 \times$ magnification. Previously only populations (not individuals) of $H$. contortus and $H$. place $i$ could be identified by studying the anatomy of at least 10 specimens to determine the percentage of the body bearing the synlophe (Lichtenfels et al., 1986), mean spicule lengths (Lichtenfels et al., 1988), or the mean distance from the left spicule barb to the distal tip (Roberts et al., 1954; Herlich et al., 1958). Previously described methods for identifying individual specimens include cytological methods (Bremner, 1955) to determine the presence or absence of a swollen chromosome in $H$. placei, and DNA polymerase chain reaction primers to amplify variable DNA spacer regions within the ribosomal DNA repeat for which diagnostic bands can be visualized by agarose gel electrophoresis (Zarlenga et al., 1993).

\section{Synlophe}

The distribution of surface cuticular ridges has been used previously by Lichtenfels et al. (1986) to distinguish populations of $H$. contortus from $H$. placei. The earlier studies (Lichtenfels et al., 1986) described only differences in the proportion of the body length bearing ridges to the unridged cuticle (the total body length in males and prevulvar length in females), but not in number and pattern of distribution of ridges in the synlophe. Gibbons (1979), who did not recognize $H$. placei, reported 32 ridges for $H$. similis and 22-30 for $H$. contortus but did not describe the pattern of distribution of the ridges. In the present study we described 30-22 ridges on $H$. contortus, 34-22 on H. placei, and 34-26 on H. similis. The more detailed description of the synlophe of $H$. contortus, $H$. placei, and $H$. similis reported herein was possible only because populations of $H$. placei and $H$. contortus could be identified with confidence using the earlier characterization of the synlophe of these species (Lichtenfels et al., 1986).

The presence (in numerous populations from a very wide geographic region, Table I) of a pair of subventral and a pair of subdorsal ridges in $H$. place $i$ and $H$. similis and the absence of these ridges in $H$. contortus (with 1 exception in which traces of subdorsal and subventral ridges were found) provided a useful character for identifying $H$. contortus. The principal value of this new synlophe character is in separating individual specimens of either sex of the similar species $H$. contortus and $H$. placei, but the difference in length of the subventral and subdorsal ridges between $H$. place $i$ and $H$. similis is also useful as a supplementary character for separating females of these species.

In the present (Table I) as well as in previous investigations, the synlophe characteristics were found to be stable irrespective of the host species (Lichtenfels, 1974, 1977; Lichtenfels and Pilitt, 1983, 1991; Beveridge and Durette-Desset, 1992). Also, specimens of the Conder et al. (1990) strain of $H$. contortus (No. 70404, Table I), which has traces of subventral and subdorsal ridges, had

anterior end, showing 25 ridges. 26. Haemonchus placei, slightly anterior to midbody, showing 22 ridges. 27. Haemonchus similis, at EI, showing 34 ridges. 28. Haemonchus similis, $4 \mathrm{~mm}$ from anterior end, showing 30 ridges. 29. Haemonchus similis, $6 \mathrm{~mm}$ from anterior end, showing 30 ridges. 30. Haemonchus similis, near midbody, showing 26 ridges. 
similar synlophe characteristics whether raised in lambs or gerbils, Meriones unguiculatus, although the nematodes from gerbils were stunted (reduced in size and development of the reproductive system). These results are consistent with a previous test of the stability of synlophe characteristics (Lichtenfels, 1974) in experimental and naturally occurring populations of Nippostrongylus braziliensis Travassos, 1914. From these studies, it appears that host effects, even when causing severe stunting of growth and development of the nematode, do not affect the number and pattern of distribution of the ridges of the synlophe.

The presence of subventral and subdorsal ridges in $H$. place $i$ and their absence in $H$. contortus was a consistent feature in all monospecific populations studied (Table I) with one exception. The Conder strain of $H$. contortus from lambs (Coll. No. 70404, Table I) and gerbils (Conder et al., 1990) had a synlophe with short, asymmetrical subventrals and subdorsals very similar to that found in experimentally produced hybrids. The possibility that the Conder strain (Conder et al., 1990) represents a hybrid was investigated. However, the reproductive vigor of this strain (Conder et al., 1990) contrasts with the extremely low reproductive potential of hybrids between $H$. contortus and $H$. placei reported by Le Jambre (1983a, 1983b). The Conder strain was identified as $H$. contortus by a DNA probe (Zarlenga et al., 1993) specific for that species.

\section{Spicule morphology}

The relatively long distance from the barbs to the distal tips of the spicules in $H$. similis, especially in the left spicule, is an easily observed character for distinguishing this species from $H$. contortus and H. placei. Gibbons (1979) showed that the relative positions of the spicule barbs are quite variable among the species of the genus Haemonchus. Thus, because of the low variability within species of this character and the large differences among species, it is a useful character for identifying males to species, especially $H$. similis.

Lichtenfels et al. (1988) showed that spicule lengths provided the quickest and easiest character to use for separating most populations of $H$. contortus and $H$. placei. Although there is considerable overlap in the range of spicule lengths of $H$. contortus and $H$. placei, Lichtenfels et al. (1988) found that small samples (10-12 specimens) from individual hosts were relatively homogeneous, and the means had small standard errors, and were usually distributed above 450 $\mu \mathrm{m}$ for $H$. placei and below $450 \mu \mathrm{m}$ for $H$. contortus. Spicule length and barb position can be used to identify $H$. similis. Thus, a study of the synlophe to determine the presence or absence of subdorsal or subventral ridges is necessary only to separate a few populations of $H$. placei or $H$. contortus with unusual spicules such as in stunted specimens, specimens in mixed infections, or hybrids; or, to confirm the identity of some female $H$. contortus or $H$. placei.

\section{Female tail length}

The conical shape and short tail length of $H$. similis females are especially useful for separating the 2 species commonly found in cattle $(H$. place $i$ and $H$. similis) in regions where they are sympatric. In the U.S.A., $H$. similis has been found only in the southern states. The shape and length of the female tail can be observed with low magnification and in combination with vulva position, living females of $H$. similis can be identified in a dish with the aid of a dissection microscope. Haemonchus contortus females have tails of intermediate lengths between those of $H$. similis and $H$. placei so the presence or absence of subventral or subdorsal ridges must be determined if the presence of $H$. contortus is suspected.

This newly recognized character of the synlophe greatly enhances the feasibility of genetic studies on these important pathogenic nematodes of sheep and cattle. Prior to this study only populations could be identified to species on the basis of the study of at least 10 specimens. Now, theoretically, individuals can be identified alive and then returned to a host and mated with another identified individual. With this new potential of identifying individual specimens to species, studies might be designed to shed some light on many mysteries of Haemonchus of sheep and cattle. For example, does one species do better in some hosts or environmental conditions? How important are gene flow and selection pressure in maintaining the specific distinctness of these closely related species under sympatric conditions? In mixed grazing conditions what happens to the nematode species composition, population levels, and effects on the hosts? The prospects for research on these nematodes are exciting indeed. 


\section{LITERATURE CITED}

BeVeridge, I., AND M. C. Durette-Desset. 1992. The morphology of Nippostrongylus magnus, a parasite of native Australian rodents. Transactions of the Royal Society of South Australia 116: 109115.

BremNER, K. C. 1955. Cytological studies on the specific distinctness of the ovine and bovine "strains" of the nematode Haemonchus contortus (Rudolphi) Cobb (Nematoda: Trichostrongylidae). Australian Journal of Zoology 3: 312-323.

Conder, G. A., L.-W. Jen, K. S. Marbury, S. S. Johnson, P. M. Guimond, E. M. Thomas, AND B. L. LEE. 1990. A novel anthelmintic model utilizing jirds, Meriones unguiculatus, infected with Haemonchus contortus. Journal of Parasitology 76: 168-170.

DinABURG, A. G. 1939. Helminth parasites collected from deer, Odocoileus virginianus, in Florida. Proceedings of the Helminthological Society of Washington 6: 102-104.

DonALD, A. D. 1963. The occurrence of Haemonchus similis Travassos, 1914 in cattle in Fiji. Journal of Helminthology 37: 179-184.

Doss, M. A., J. D. Rayburn, J. H. Shaw, AND M. D. KIRBY. 1985. Nematoda and nematode diseases. Supergenera, genera, species and subspecies: F-M. Index-Catalogue of medical and veterinary zoology. Special Publication No. 6, Part 3, Issued July 1985, U.S. Department of Agriculture, Agricultural Research Service, U.S. Government Printing Office, Washington, D.C., 556 p.

DutT, S. C., AND B. N. SahaI. 1966. Redescriptions of Haemonchus longistipes Railliet and Henry, 1909 and $H$. bispinosus (Molin, 1860) with remarks on the taxonomic status of $H$. placei (Place, 1893) (Nematoda: Trichostrongylidae). Indian Journal of Helminthology 18: 104-113.

Gibbons, L. M. 1979. Revision of the genus Haemonchus Cobb, 1898 (Nematoda: Trichostrongylidae). Systematic Parasitology 1: 3-24.

GibBS, H. C., AND R. P. HeRD. 1986. Nematodiasis in cattle: importance, species involved, immunity, and resistance. In The veterinary clinics of North America. Parasites: Epidemiology and control, Vol. 2, No. 2, H. C. Gibbs, R. P. Herd, and K. D. Murrell (eds.). W. B. Saunders Company, Philadelphia, p. 211-224.

Herlich, H., D. A. Porter, ANd R. A. KNight. 1958. A study of Haemonchus in cattle and sheep. American Journal of Veterinary Research 19: 866-872.

Le JAMBre, L. F. 1983a. Pre-mating barriers to species hybridization in Haemonchus. International Journal for Parasitology 13: 365-370.

- 1983b. Pre-mating barriers in hybrid Haemonchus. International Journal for Parasitology 13: 371-375.

LiCHTENFELS, J. R. 1974. Number and distribution of ridges in the cuticle of Nippostrongylus brasiliensis (Travassos, 1914) (Nematoda: Heligmosomatoidea). Journal of Parasitology 60: 285-288. - 1977. Differences in cuticular ridges among Cooperia spp. of North American ruminants with an illustrated key to species. Proceedings of the Helminthological Society of Washington 44: 111119.

1980. Keys to genera of the superfamily Strongyloidea. In $\mathrm{CIH}$ keys to the nematode parasites of vertebrates, No. 7, R. C. Anderson, A. G. Chabaud, and S. Willmott (eds.). Commonwealth Agricultural Bureaux, Farnham Royal, Bucks, England, 41 p.

- , AND P. A. PilitT. 1983. Cuticular ridge patterns of Nematodirus (Nematoda: Trichostrongyloidea) parasitic in domestic ruminants of North America with a key to species. Proceedings of the Helminthological Society of Washington 50: 261274.

$\longrightarrow$, AND - 1991. A redescription of Ostertagia bisonis (Nematoda: Trichostrongyloidea) and a key to species of Ostertaginae with a tapering lateral synlophe from domestic ruminants in North America. Journal of the Helminthological Society of Washington 58: 231-244.

$\longrightarrow,-,-$ AND L. F. LE JAMBre. 1986. Cuticular ridge patterns of Haemonchus contortus and Haemonchus placei (Nematoda: Trichostrongyloidea). Proceedings of the Helminthological Society of Washington 53: 94-101.

$\longrightarrow, \longrightarrow$ AND $\longrightarrow$ 1988. Spicule lengths of the ruminant stomach nematodes Haemonchus contortus, Haemonchus placei, and their hybrids. Proceedings of the Helminthological Society of Washington 55: 97-100.

LiNS DE AlmeidA, J. 1935. Revisão do genero Haemonchus Cobb, 1898. (Nematoda: Trichostrongylidae). Memorias do Instituto Oswaldo Cruz 30: 57-114.

Roberts, F. H. S., H. N. Turner, AND M. McKeVett. 1954. On the specific distinctness of the ovine and bovine "strains" of Haemonchus contortus (Rudolphi) Cobb (Nematoda: Trichostrongylidae). Australian Journal of Zoology 2: 275-295.

Steel, R. G. D., AND J. H. Torrie. 1960. Principles and procedures of statistics. McGraw-Hill Book Co., New York, 481 p.

VeGLIA, F. 1915. The anatomy and life-history of the Haemonchus contortus (Rud). Third and Fourth Annual Reports of the Director of Veterinary Research, Union of South Africa, Pretoria, p. 349500.

Zarlenga, D. S., F. STRINGFellow, M. Nobary, AND J. R. LiCHTENFELS. 1994. Cloning and characterization of ribosomal RNA genes from three species of Haemonchus (Nematoda: Trichostrongyloidea). Experimental Parasitology (in press). 